\title{
Factors Influencing Online Purchase Intention of Shopee's Consumers in Malaysia
}

Lee Jing Ru, Tan Owee Kowang, Choi Sang Long, Fong Sook Fun, Goh Chin Fei

To Link this Article: http://dx.doi.org/10.6007/IJARBSS/v11-i1/8577

DOI:10.6007/IJARBSS/v11-i1/8577

Received: 09 November 2020, Revised: 07 December 2021, Accepted: 10 January 2021

Published Online: 27 January 2021

In-Text Citation: (Ru et al., 2021)

To Cite this Article: Ru, L. J., Kowang, T. O., Long, C. S., Fun, F. S., \& Fei, G. C. (2021). Factors Influencing Online Purchase Intention of Shopee's Consumers in Malaysia. International Journal of Academic Research in Business and Social Sciences, 11(1), 761-776.

\section{Copyright: (c) 2021 The Author(s)}

Published by Human Resource Management Academic Research Society (www.hrmars.com)

This article is published under the Creative Commons Attribution (CC BY 4.0) license. Anyone may reproduce, distribute, translate and create derivative works of this article (for both commercial and non-commercial purposes), subject to full attribution to the original publication and authors. The full terms of this license may be seen at: http://creativecommons.org/licences/by/4.0/legalcode

Vol. 11, No. 1, 2021, Pg. 761 - 776

Full Terms \& Conditions of access and use can be found at http://hrmars.com/index.php/pages/detail/publication-ethics 


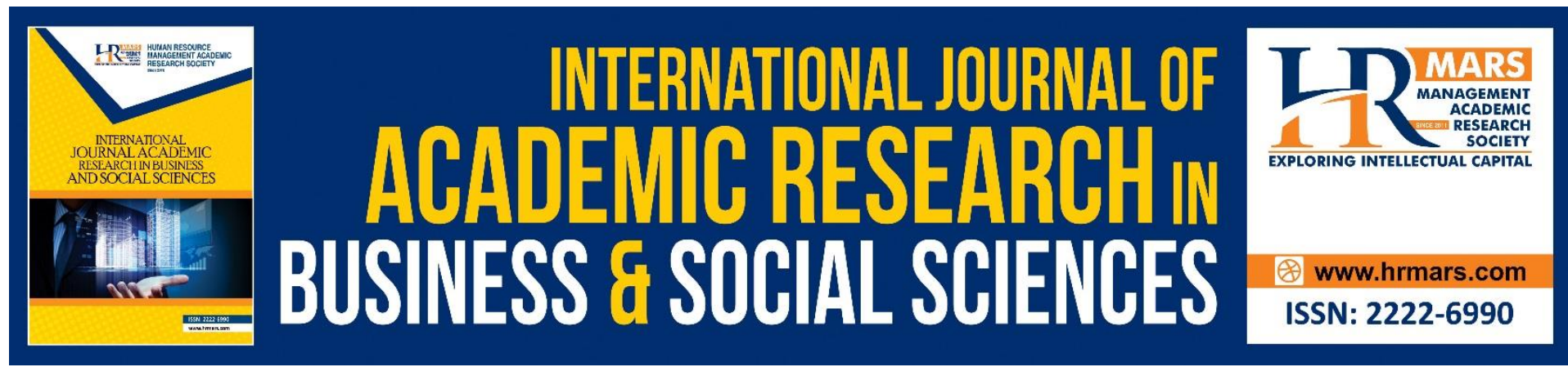

\title{
Factors Influencing Online Purchase Intention of Shopee's Consumers in Malaysia
}

\author{
${ }^{1}$ Lee Jing Ru, ${ }^{2}$ Tan Owee Kowang, ${ }^{1}$ Choi Sang Long, ${ }^{1}$ Fong \\ Sook Fun, ${ }^{2}$ Goh Chin Fei
}

${ }^{1}$ Faculty of Business, Raffles University, Johor Bahru, Malaysia, ${ }^{1}$ Azman Hashim International Business School, Universiti Teknologi Malaysia, Johor, Malaysia.

Email: oktan@utm.my

\begin{abstract}
The purpose of this study is to investigate the factors influencing online purchase intention of an e-commerce platform at Johor Bahru, Malaysia. This research selected Shopee Malaysia as the target e-commerce platform and a few variables from Technology Acceptance Model (TAM) and Theory of Planned Behaviour (TPB) tend to be used and analyzed the online purchase intention of Shopee's consumers. Online purchase intention can be defined as a situation when an individual plan to purchase a particular good or service through the internet. Hence, it is important to analyze how the four dimensions tend to influence the overall online purchase intention in the e-commerce industry. In Malaysia, e-commerce business is gradually expanding, and it is significant for online retailers to clearly understand which dimensions enable to stand out among other competitors and increase online purchase intention. Data for this study were collected from a sample of 90 guests who live in Johor Bahru and had experienced in purchasing products via Shopee Malaysia. The collected data was analyzed using Statistical Package for Social Science (SPSS) version 23.0 and Partial Least Squares (PLS-SEM) with SmartPLS version 3. The findings revealed that two dimensions which are perceived usefulness and subjective norm positively influence online purchase intention whereas, two dimensions which are perceived ease of use and trust do not have a significant impact. As a result, it is suggested for Shopee Malaysia to appropriately apply relevant specific tactics to enhance those components as well as online purchase intention.
\end{abstract}

Keywords: Online Purchase Intention, E-Commerce Industry, Technology Acceptance Model and Theory of Planned Behaviour

\section{Introduction}

The advanced of technology nowadays provides greater opportunities for Malaysians to conduct both business and shop online. E-commerce has become popular in today's world either for business-to-business (B2B), business-to-consumer (B2C), or consumer-to-consumer (C2C) e-commerce. According to Khatibi and Seetharaman (2003), internet has transformed the traditional model and system and it is also function as a communication medium that allows buyers and sellers to interact with each other online. Malaysian Communications and Multimedia Commission (2019) stated that there is an increasing of consumers in Malaysia 
doing online shopping and which is from 48.8 percent of the consumers in Malaysia purchase things online in 2016 increases to 53.5 percent of consumers in year 2018. There are a lot of e-commerce platforms such as Lazada, Taobao, Zalora, and Shopee is also one of it. However, many of the local companies in Malaysia have a lack of understanding and knowledge on consumer's attitudes towards online shopping (Harn, Khatibi, \& Ismail, 2006). Besides that, it is found that Malaysians prefer brick and mortal shopping compared to brick and click shopping as they gain less trust towards online shopping (Chin, 2016). Another problem that will affects e-commerce industry is there is a report showed that consumers like to discover or get the information online but at the end, they will make their final purchase at the physical stores (TimeTrade, 2019). Hence, it is essential for the Shopee Malaysia to study and concern which dimensions tend to have a serious influence on the online purchase intention among its customers. Hence, the objective of this study is to examine the relationship between perceived usefulness, perceived ease of use, trust and subjective norm (independent variables) and online purchase intention (dependent variable).

\section{Literature Review}

\section{Technology Acceptance Model (TAM)}

Technology Acceptance Model (TAM) is used to predict the consumer behaviour in making decision of purchasing goods or services online (Koththagoda \& Herath, 2018). TAM was first developed by Davis (1989) and is commonly used to explain the level of technology acceptance of users. This model that formulated by Davis is the adoption of Theory of Reasoned Action (TRA). TAM comes out with two important variables which are perceived usefulness (PU) and perceived ease of use (PEOU). On the other hand, attitude is also found has partially mediated the effects of perceived usefulness and ease of use on intention to use. It shows that these two variables have a strong impact towards the consumer attitude on technology acceptance and it also explain the intention to use technology (Koththagoda \& Herath, 2018). To relate TAM to the factors that influencing online purchase intention, it can be said that perceived usefulness and perceived ease of use are found to have significant influence towards the intention of the consumers to purchase things online.

\section{Theory of Planned Behaviour (TPB)}

According to Ajzen (1991), the Theory of Planned Behaviour (TPB) is the extension of the Theory of Reasoned Action (TRA) due to the limitations in the previous theory in dealing with behaviours over which people have incomplete volitional control. In the TRA model, it is stated that the motivational factors that influence an individual's intention to perform a behaviour. However, the behavioural intention will perform only if the behaviour in question is under volitional control. On the other hand, TPB model developed a better explanation of behavioural model which depends jointly on the intention of an individual to perform certain behaviour and the ability of the individual to actual control over the behaviour. Subjective norm, attitude toward behaviour and perceived behavioural control are used to predict behavioural intentions. In this model, it shows that there is a significant relationship between these variables in affecting a person's attitude and behaviour towards online purchase intention.

\section{Perceived Usefulness}

Perceived usefulness is defined as the degree to which a person believes that using a particular system would enhance his or her performance (Davis, 1989). It means that an 
individual will only have the intention to use the technology to purchase things online when they found out that it is useful for them. It is also defined as the degree that the consumers feel about the online website could bring value and efficacy to them when they are undergoing online buying. Besides that, the perceived usefulness of the online website usually depends on the efficiency of technological characteristics. For example, the advances search engines and the service provided to the consumers. Furthermore, it is also important to provide various information and detailed product's descriptions on the website to allow the consumers to obtain the product's information that they want to look at and help them in making purchase decision (Lim, Osman, Salahuddin, Romle, \& Abdullah, 2015). According to Chiu, Ling and Tang (2005), if it needs consumer to take a long period of time to search on a certain product, the consumer will perceive the website is not useful and the intention to purchase online decreases as consumers prefer the readily available and useful information on the websites to help them to make the purchase decisions efficiently. Besides that, consumers demand for a reliable and good information to make purchase decision online is because they are unable to touch and test the product through online (Tan, Goh, Stany \& Yeow, 2017). In addition, previous studies on perceived usefulness were mostly conducted in developing countries such as China (Zhao \& Cao, 2012), Malaysia (Letchumanan \& Muniandy, 2013), Vietnam (Nguyen \& Barrett, 2006) and Iran (Aghdaie et al., 2011). It is because developing countries are still at the infant stage of information technology compared to developed countries (Hana, Mike \& Parvaneh, 2012).

H1: There is a significant relationship between perceived usefulness and online purchase intention.

\section{Perceived Ease of Use}

Perceived ease of use is known as the degree to which a person believes that using a particular system would be free of effort (Davis, 1989). It also relates to the customers' belief on how efficient is the website that can help them to search more information with less effort (Chiu, Ling \& Tang, 2005). Ease of use can be the ease of ordering, functionality, navigation of website and accessibility of information in the e-commerce context (Reibstein, 2002). The design of the website is vital for a company. A user-friendly system in the website will increases online purchase intention (Chiu, Ling \& Tang, 2005). Furthermore, a good quality web design increases customer satisfaction and will leads to a higher online purchase intention (Lee $\&$ Lin, 2005). A good website design should be readable, visually appealing and tidy for the consumers to use it easily. Therefore, perceived ease of use is an important factor that will influence online purchase intention.

$\mathrm{H} 2$ : There is a significant relationship between perceived ease of use and online purchase intention.

\section{Trust}

Trust is an important element in E-commerce (Chen \& Barnes, 2007; Thamizhvanan \& Xavier, 2013; Cheng \& Yee, 2014). It is because of there is a minimal face-to-face interaction occurs between online retailer and consumers. Furthermore, it refers to the consumer perception towards online retailer's behaviour such as their ability, fairness and honesty (McKnight \& Chervany, 2001). According to Cheng and Yee (2014), the main dimensions of online trust are security, reliability and privacy. Therefore, consumers who perceive their privacy information 
are protected will increases their online purchase intention (Chiu, Ling \& Tang, 2005; Liu, et al, 2019). Most of the time, consumers will assume that large organizations are more reliable to them and it influences them to have the intention to purchase products from them online (Cheng \& Yee, 2014). If the consumers perceived the online transaction is risky, their trust towards the online purchase will also decreases. The examples of the behaviour that will reduce trust from consumers towards online purchase are such as unfair pricing, inaccurate information, violations of privacy, unauthorized tracking of transactions, and unauthorized use of credit card information of consumers (Gefen, Karahanna, \& Straub, 2003). Hence, online retailers should always focus on delivering trust and transparency value to the customers in order to increase the consumer's online purchase intention and at the same time to build a long-term relationship with them. It will also increase their confident towards online purchase.

$\mathrm{H} 3$ : There is a significant relationship between trust and online purchase intention.

\section{Subjective Norm}

Subjective norm refers to the perceived social pressure of consumers that influence them to perform certain behaviour (Ajzen, 1991). It was derived from Theory of Reasoned Action (TRA). In E-commerce, subjective norm refers to the consumer's perceived social pressure in increasing their intention to purchase products from the online stores. If an individual has no idea about where and how to get certain products, he or she might seek for the opinions from the people surrounding them such as friends and family members. Then, most of them will influence by them and decide to follow what they say (Cheng \& Yee, 2014). Moreover, it also shows that a person will be easily influenced by someone who they think is important to him or her including encourage or convince he or she to make online shopping (See, Nor, \& AlAgaga, 2012). In the aspect of online shopping, subjective norm shows a direct impact towards online purchase intention.

$\mathrm{H} 4$ : There is a significant relationship between subjective norm and online purchase intention. Online Purchase Intention

Online shopping occurs must be come from the consumer's intention to purchase things online. Intention comes from the extent of conscious effort that an individual will follow to approve his or her behaviour and it is also considered as one of the motivational components of behaviour. Moreover, consumer's purchase intention will usually occur when he or she is planned to purchase any goods and services in the future. Hence, in a simple word, online purchase intention can be known as a situation when an individual plan to purchase a particular good or service through the internet (Cheng \& Yee, 2014). In the development of electronic commerce, lack of online purchase intention could become the main barrier. Hence, it is important for the online business retailer to study about the online purchase intention of consumes and the factors that influencing online purchase intention. It is because every transaction activity either physical or virtual usually starts with an intention (Hasan, Harun, \& Rashid, 2015). 


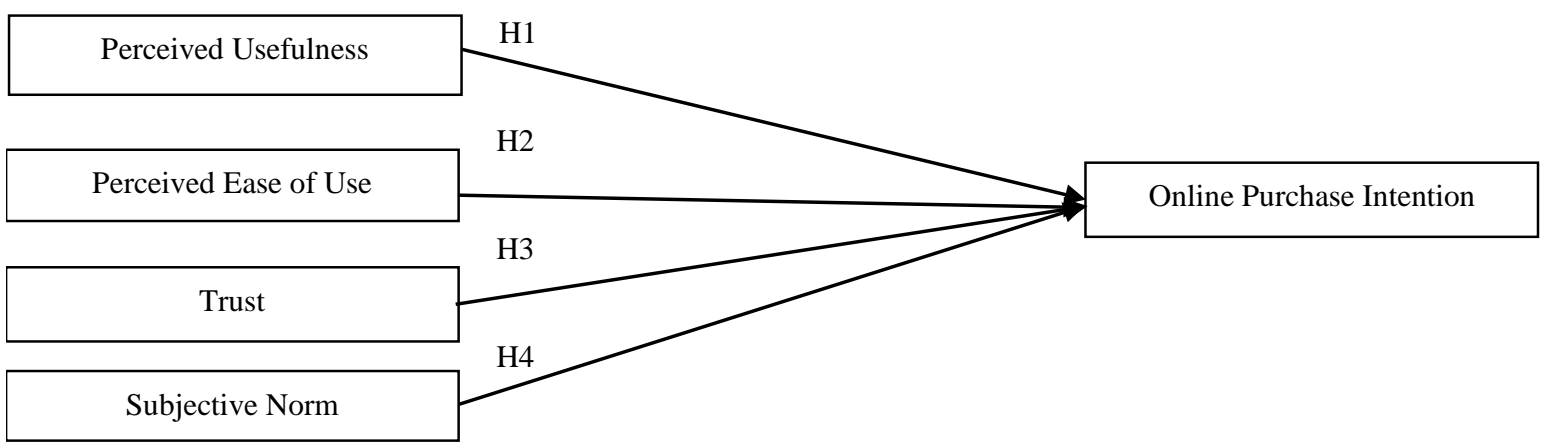

Figure 1: Conceptual Framework

\section{Research Methodology \\ Data Collection and Measures}

Data of this research study is gathered from the consumers who live in Johor Bahru and had experienced in purchasing products via Shopee Malaysia. This research adopted a nonprobability sampling technique which is convenient sampling. According to Elfil and Negida (2017), this type of sampling is quick, inexpensive and convenient method to collect the sampling data. The reason it called convenient sampling is due to the researcher will selects the sample elements according to their convenient accessibility and proximity. The data collected by distributing online questionnaires to respondents. The questionnaire was divided into 3 sections and contained a total of 24 questions. The first section enclosed questions about respondents' demographic profile and background information. The second section was related to study respondents' perception on the four dimensions that Shopee Malaysia offered. The researcher sent online survey link through e-mailing and messaging to collect the data. A sum of 90 respondents participated in this research study. The process of distribution and collection of the questionnaires took three months to complete. The five-point Likert scale ( 1 = strongly disagree, 2 = disagree, 3 = neutral, $4=$ agree and $5=$ strongly agree) was developed for respondents to answer those relevant questions that listed in the questionnaire. The questionnaire was adapted from previous research, namely Agyapong (2018), Aineah (2016), Athapaththu \& Kulathunga (2018), as well as Alatawy1 (2018).

\section{Data Analysis and Findings}

Partial Least Squares (PLS-SEM) with SmartPLS version 3 and Statistical Package for Social Sciences (SPSS) version 23.0 software were used to analyze the collected data. SPSS was used to analyze the relevant descriptive statistics whereas, SmartPLS was applied to investigate the relationship between perceived usefulness, perceived ease of use, trust and subjective norm (independent variables) and online purchase intention (dependent variable). 


\section{Respondent Background}

Table 1 shown the summary of respondents' background

Table 1: Respondents' Background

\begin{tabular}{lccc}
\hline Background & Categories & Frequency & Percentage (\%) \\
\hline Gender & Male & 34 & 37.8 \\
& Female & 56 & 62.2 \\
\hline Age & $15-19$ & 14 & 15.6 \\
& $20-25$ & 43 & 47.8 \\
& $26-30$ & 15 & 12.7 \\
& $31-35$ & 11 & 7.8 \\
\hline Monthly Income & Above 35 & 7 & 21.1 \\
& RM500 & 13.3 \\
& RM501-RM1000 & 12 & 28.9 \\
& RM1000-RM3000 & 26 & 28.9 \\
\hline Frequency to Shop Online & RM3001-RM5000 & 26 & 7.8 \\
& Above RM5000 & 7 & 27.8 \\
& Once a month & 25 & 25.6 \\
& More than once a month & 23 & 25.6 \\
& 2-11 times a year & 23 & 21.1 \\
\hline
\end{tabular}

Based on Table 1, below it revealed the demographic data of respondents which were slightly less males (37.8\%) than females (62.2\%). Besides that, most of the respondents were aged between 20 and 25 years old (47.8\%), followed by between 26 and 30 (16.7\%), between 15 and 19 (15.6\%), between 31 and 35 (12.2\%), and lastly above 35 (7.8\%). Furthermore, most of the respondents' monthly income were between RM1000 to RM3000 (28.9\%) and between RM3001 to RM5000 (28.9\%), then followed by RM500 (21.1\%), RM501 to RM1000 (13.3\%), and above RM5000 (7.8\%). Lastly, most of the respondents undergo online shopping once a month which contributed $27.8 \%$ among the respondents.

\section{Reliability Analysis}

Reliability analysis is measured by Cronbach's Alpha and composite reliability (CR). Table 2 showed that the value of Cronbach's Alpha for all variables ranges from 0.745 to 0.874 . In fact, each variable is considered acceptable due to each value which is greater than 0.70 will be defined as reliable (Nunnally, 1978).

Table 2: Results of Reliability Test

\begin{tabular}{lccc}
\hline Variables & Number of Item & Cronbach's Alpha & CR \\
\hline $\begin{array}{l}\text { Online Purchase } \\
\text { Intention }\end{array}$ & 4 & 0.874 & 0.914 \\
\hline Perceived Usefulness & 4 & 0.836 & 0.891 \\
\hline Perceived Ease of Use & 4 & 0.852 & 0.900 \\
\hline Trust & 4 & 0.812 & 0.877 \\
\hline Subjective Norm & 4 & 0.745 & 0.837 \\
\hline
\end{tabular}

From Table 2, it also showed that the value of composite reliability for all variables ranges from 0.837 to 0.914 . Therefore, each variable is considered reliable as each value must be at least 0.6 to receive a relevant composite reliability finding (Awang, 2012).

\section{Construct Validity}

Construct validity is vital for the empirical measures and hypothesis testing for the construction of theories (Mohajan, 2017). The theoretical constructs that came out by researchers are used to better understand, explain, and predict the behaviour (Thatcher, 
2010). It comprises testing a scale in terms of theoretically derived hypotheses concerning the nature of underlying variables or constructs (Pallant, 2011). Furthermore, it is used to verify that the measure is actually measure what it is intended to measure, and which is not other variables (Twycross \& Shields, 2004). Construct validity includes two components which are convergent validity and discriminant validity. Each item loading will be considered has a positive relationship when the results are greater than 0.5 (Hair, Black, Babin, \& Anderson, 2010). Based on the results that revealed in Table 3, all items were resulted in highly on that construct, then the test result was perfectly confirming that data are valid to be applied for further analysis.

Table 3: Each Item Loading Results

\begin{tabular}{|c|c|c|c|c|c|}
\hline & $\begin{array}{l}\text { Perceived } \\
\text { Usefulness }\end{array}$ & $\begin{array}{c}\text { Perceived Ease } \\
\text { of Use }\end{array}$ & Trust & $\begin{array}{l}\text { Subjective } \\
\text { Norm }\end{array}$ & $\begin{array}{c}\text { Online Purchase } \\
\text { Intention }\end{array}$ \\
\hline PU1 & 0.854 & & & & \\
\hline PU2 & 0.759 & & & & \\
\hline PU3 & 0.850 & & & & \\
\hline PU4 & 0.809 & & & & \\
\hline PEOU5 & & 0.851 & & & \\
\hline PEOU6 & & 0.865 & & & \\
\hline PEOU7 & & 0.846 & & & \\
\hline PEOU8 & & 0.763 & & & \\
\hline T9 & & & 0.808 & & \\
\hline T10 & & & 0.775 & & \\
\hline T11 & & & 0.776 & & \\
\hline T12 & & & 0.839 & & \\
\hline SN13 & & & & 0.844 & \\
\hline SN14 & & & & 0.718 & \\
\hline SN15 & & & & 0.631 & \\
\hline SN16 & & & & 0.797 & \\
\hline OPI1 & & & & & 0.798 \\
\hline OPI2 & & & & & 0.893 \\
\hline OPI3 & & & & & 0.861 \\
\hline OPI4 & & & & & 0.855 \\
\hline
\end{tabular}

\section{Convergent Validity}

Convergent validity refers to the extent to which scores on a measure share a high, medium or low relationship with scores obtained on a different measure intended to assess the similar construct (Messick, 1995). It is the degree to which two variables are measured separately carry a relationship to one another (Straub, 1989). The indicator is known as average variance extracted (AVE) which use to examine and verify convergent validity (Hair, Black, Babin, \& Anderson, 2010). The value of variance for AVE should be higher than 0.5 to ensure the result of construct validity is valid to be used (Awang, 2012). 
Table 4: Results of Measurement Model for Convergent Validity

\begin{tabular}{|c|c|c|c|c|}
\hline Construct & Items & Loadings & AVE & CR \\
\hline Perceived & PU1 & 0.854 & & \\
\hline \multirow[t]{3}{*}{ Usefulness } & PU2 & 0.759 & 0.671 & 0.891 \\
\hline & PU3 & 0.850 & & \\
\hline & PU4 & 0.809 & & \\
\hline \multirow{4}{*}{$\begin{array}{l}\text { Perceived Ease of } \\
\text { Use }\end{array}$} & PEOU5 & 0.851 & & \\
\hline & PEOU6 & 0.865 & 0.693 & 0.900 \\
\hline & PEOU7 & 0.846 & & \\
\hline & PEOU8 & 0.763 & & \\
\hline \multirow[t]{4}{*}{ Trust } & T9 & 0.808 & & \\
\hline & $\mathrm{T} 10$ & 0.775 & 0.640 & 0.877 \\
\hline & $\mathrm{T} 11$ & 0.776 & & \\
\hline & $\mathrm{T} 12$ & 0.839 & & \\
\hline \multirow[t]{4}{*}{ Subjective Norm } & SN13 & 0.844 & & \\
\hline & SN14 & 0.718 & 0.565 & 0.837 \\
\hline & SN15 & 0.631 & & \\
\hline & SN16 & 0.797 & & \\
\hline Online Purchase & OPI1 & 0.798 & & \\
\hline \multirow[t]{3}{*}{ Intention } & OPI 2 & 0.893 & 0.727 & 0.914 \\
\hline & OPI3 & 0.861 & & \\
\hline & OPI4 & 0.855 & & \\
\hline
\end{tabular}

Based on Table 4, the range of AVEs was shown between 0.565 and 0.727 , thus it revealed the acceptable value was computed. Furthermore, each loading items can be explained to have a positive relationship when the result of more than 0.5 are presented (Hair, Black, Babin, \& Anderson, 2010). Based on Table 4, the range of each loading items was shown between 0.631 and 0.893 which revealed the acceptable value was computed.

\section{Discriminant Validity}

Fornell-Larcker Criterion is used in this research to analyze and validate the discriminant validity. Discriminant validity is the degree to which latent variable differentiates from other latent variables (Taherdoost, 2016). It refers to a latent variable can account for more variance in the observed variables associated with it than measurement error or similar external, unmeasured influences, or other constructs within the conceptual framework. Each items value must be slightly higher than its construct which indicates that the variance shared among its construct must be greater than when it shared between other constructs (Compeau, Higgins, \& Huff, 1999). The researcher can understand the correlation coefficients for every construct through measuring the square root of each construct's AVE by using Smart PLS (Fornell \& Larcker, 1981). Based on the results that revealed in Table 5, it demonstrates acceptable discriminant validity due to those measurement models enable to completely support the discriminant validity between the five constructs in this research study.

Table 5: Discriminant Validity - Fornell-Larcker Criterion

\begin{tabular}{lccccc}
\hline Construct & $\mathbf{1}$ & $\mathbf{2}$ & $\mathbf{3}$ & $\mathbf{4}$ & $\mathbf{5}$ \\
\hline 1.Online Purchase Intention & $\mathbf{0 . 8 5 2}$ & & & & \\
\hline 2.Perceived Ease of Use & 0.639 & $\mathbf{0 . 8 3 2}$ & & & \\
\hline 3.Perceived Usefulness & 0.743 & 0.683 & $\mathbf{0 . 8 1 9}$ & & $\mathbf{0 . 7 5 2}$ \\
\hline 4.Subjective Norm & 0.651 & 0.546 & 0.644 & 0.587 & $\mathbf{0 . 8 0 0}$ \\
\hline 5.Trust & 0.642 & 0.589 & 0.691 & \\
\hline
\end{tabular}




\section{Path Coefficient and Hypotheses Testing}

Path coefficients is known as the standardized versions of linear regression weights which can be used in determining the possible causal linkage between statistical variables in the structural equation modeling approach (Hair, Hult, Ringle \& Sarstedt, 2017). The standardization includes multiplying the ordinary regression coefficient by the standard deviations of the corresponding explanatory variable while these can then be compared to assess the relative effects of the variables within the fitted regression model. Furthermore, the idea of standardization can be extended to apply to partial regression coefficients. Then, a particular diagram-based approach was used to consider the relations between variables in a multivariate system (Wright, 1921). Based on Figure 2 and Table 6, the R Square value was 0.633 which commented that $63.3 \%$ of the variance in the online purchase intention can be explained by the four dimensions, namely, perceived usefulness, perceived ease of use, trust, and subjective norm. Perceived usefulness was significantly related $(\beta=0.380, p<0.05, t$ $>1.645)$ to online purchase intention, as was subjective norm $(\beta=0.230, p<0.05, t>1.645)$. In contrast, perceived ease of use and trust were not generated a positive impact on overall online purchase intention. Therefore, $\mathrm{H} 1$ and $\mathrm{H} 4$ of this research study are supported whereas, $\mathrm{H} 2$ and $\mathrm{H} 3$ are not supported. In truth, it was noticed that perceived usefulness tends to have the most significant influence on online purchase intention of Shopee's consumers in Johor Bahru, Malaysia due to there is approximately more than half of the $R$ Square value is retrieved from perceived usefulness.

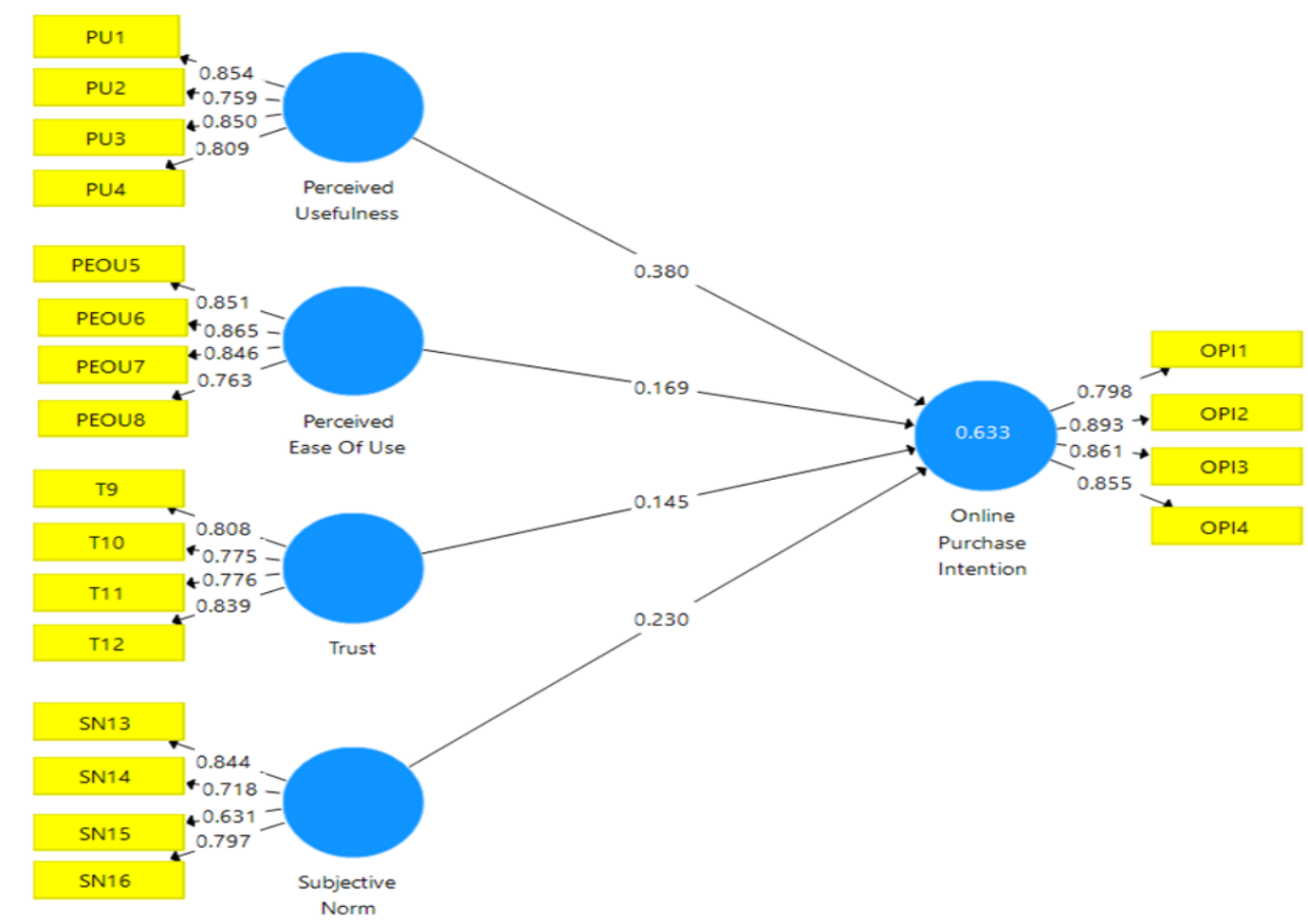

Figure 2: Structural Framework 
INTERNATIONAL JOURNAL OF ACADEMIC RESEARCH IN BUSINESS AND SOCIAL SCIENCES Vol. 11, No. 1, 2021, E-ISSN: 2222-6990 @ 2021 HRMARS

Table 6: Path Coefficients and Hypotheses Testing

\begin{tabular}{|c|c|c|c|c|c|c|}
\hline Hypotheses & Relationship & $\begin{array}{l}\text { Std. } \\
\text { Beta }\end{array}$ & T Value & P Value & Decision & $\mathbf{R}^{2}$ \\
\hline H1 & $\begin{array}{l}\text { Perceived Usefulness -> } \\
\text { Online Purchase Intention } \\
\end{array}$ & 0.380 & 3.402 & 0.000 & Supported & \multirow{4}{*}{0.633} \\
\hline $\mathrm{H} 2$ & $\begin{array}{c}\text { Perceived Ease of Use -> } \\
\text { Online Purchase } \\
\text { Intention } \\
\end{array}$ & 0.169 & 1.606 & 0.054 & Not Supported & \\
\hline $\mathrm{H} 3$ & $\begin{array}{c}\text { Trust -> Online Purchase } \\
\text { Intention }\end{array}$ & 0.145 & 1.372 & 0.085 & Not Supported & \\
\hline $\mathrm{H} 4$ & $\begin{array}{c}\text { Subjective Norm -> Online } \\
\text { Purchase Intention }\end{array}$ & 0.230 & 1.930 & 0.027 & Supported & \\
\hline
\end{tabular}

\section{Hypotheses Discussion}

\section{H1: There is a significant relationship between perceived usefulness and online purchase} intention.

The results showed that $\mathrm{H} 1$ is accepted, which means there is a significant relationship between perceived usefulness and online purchase intention of Shopee's consumers in Johor Bahru, Malaysia. According to Hasan, Harun, and Rashid (2015), the usefulness of the website is important to increase the consumers' intention to purchase and to avoid losing the potential customers. Furthermore, trust among new consumers towards the website can be build due to the usefulness of the online websites which then leads to their intention to purchase product through online. The usefulness of the Shopee's website will also help the consumers to save more money and spend less time during online shopping. Besides that, Cha (2011) stated that perceived usefulness is essential for online shopping because one online retailer not only competes with other online retailers, but also competes with offline retailers. Thus, the details and resourceful information about the goods and services that provided by an online store like Shopee helps satisfy the customers' needs and influences the consumers to undergo online shopping. According to Koufaris and Sosa (2004), perceived usefulness for online purchases is important as it is a consumer's subjective probability thinking that Internet usage will efficiently smoothen the progress of purchase. If the websites of an e-commerce platform is not useful in enhancing the consumers' purchasing, then the consumers will just stick back to the old way to purchase products such as buy the products that they want in a brick and mortar shop since they are familiar with the way already (See, Nor, \& Al-Agaga, 2012). As a result, perceived usefulness has a positive relationship to online purchase intention. Thus, Shopee is required to strengthen its components of perceived usefulness by providing a useful website to ensure that they can satisfy the online customers' needs and wants and influence them to make a purchase or repeat purchase in Shopee.

\section{H2: There is a significant relationship between perceived ease of use and online purchase intention.}

The final test results do not support $\mathrm{H} 2$, which means there is no relationship between perceived ease of use and online purchase intention of Shopee's consumers in Johor Bahru, Malaysia. According to Cheng and Yee (2014), the ease of use of a website sometimes can only attract consumers to shop and search for the information on products that they desire to know more. In spite of that, it does not necessarily mean that the consumers will purchase the products via online as most of them may merely want to obtain the information online and then purchase the products at another channel such as physical store. It means that the consumers may only want to search for product information in Shopee but not going to buy 
the products in Shopee. Sometimes, society culture may be one of the reasons that causes the influence of perceived ease of use on intention to shop online to be not significant as some consumers may like to use their shopping time to have fun and to socialize in the nearer physical shop (Juniwati, 2014). Hence, it means that Shopee's customers do not seek ease of use when undergoing online buying at Shopee's website.

\section{H3: There is a significant relationship between trust and online purchase intention.}

The final test results also do not support $\mathrm{H} 3$, which means there is no relationship between trust and online purchase intention of Shopee's consumers in Johor Bahru, Malaysia. According to Rehman (2018), trust has insignificant effect on online purchase intention. It shows that trust in the company does not have to be a necessary condition to purchase online (Tan \& Thoen, 2001). It means that Shopee's customers purchase products from Shopee website is because of other reasons rather than trust towards Shopee.

\section{H4: There is a significant relationship between subjective norm and online purchase intention.}

Based on the analysis of results, $\mathrm{H} 4$ is accepted, which means there is a significant relationship between subjective norm and online purchase intention of Shopee's consumers in Johor Bahru, Malaysia. According to Tan, Goh, Stany and Yeow (2017), it is indicated that consumer may be influenced by the opinions and comments posted by other users during the purchasing process as friends, family, peers, co-workers and individuals or group of individuals who are related to a person behavioural intention can alter a person's thought, thinking and action. Hence, it showed that most of the Shopee's consumers in Johor Bahru undergo online shopping via Shopee website is due to the social influences such as recommendations and comments from the people surroundings or other online users. In addition, consumers commonly make judgments will seek information from various external sources such as experts or opinion leaders first to reduce uncertainty about credibility. Generally, consumers do not rely on one particular source or internal information only (Athapaththu \& Kulathunga, 2018). It means that Shopee's consumers in Johor Bahru would like to seek others' opinions first before making the purchase in Shopee.

\section{Discussion and Conclusion}

In this section, the researcher provides relevant recommendations for Shopee Malaysia to increase the online purchase intention of its customers. The results obtained from this study reveals that the online purchase intention of Shopee's consumers in Johor Bahru, Malaysia are significant affected by perceived usefulness and subjective norm. In contrast, there are two components which are perceived ease of use and trust do not result to have positive impact. Therefore, it is important for Shopee Malaysia to emphasize on these two variables which have a positive relationship towards online purchase intention of Shopee's consumers in Malaysia.

Perceived usefulness should be attentively concerned by Shopee Malaysia as it is the strongest factor in influencing the online purchase intention which obtained the highest beta value among other components. First, Shopee as an e-commerce platform should make sure that the website condition is always stable and the maintenance for the websites are required to be conducted continuously. Koththagoda and Herath (2018) shared that online shoppers expect a useful function of an online website. Hence, Shopee should design a user-friendly 
interface and platform in order to provide more efficient and effective services such as a search mechanism that can provide relevant information and also facilitate product comparison that helps the consumers to make their best decisions in a most efficient way. Besides that, the information or the descriptions of the products that provided by Shopee should be clear to avoid the customers' confusion. Hence, Shopee should always organize and screen their online content well. Lastly, Shopee can always ask for consumers' opinions regarding to the additional functions that they expect to find in Shopee, so that Shopee can try to design and add it into Shopee's website.

The second component which is vital for Shopee Malaysia to increase the online purchase intention of Shopee's consumers in Malaysia is subjective norm. Firstly, Shopee can provide a balanced perspective in their websites by including opinions from customers who have purchased the items previously, as well as opinions from experts on specific areas due to consumers seek good testimonials, feedbacks and reviews all the time before they undergo the purchasing process (Cheng \& Yee, 2014; Dharmesti, et al, 2019). Furthermore, Shopee can also build a rapport relationship with their existing customers so that they will help to spread the positive word of mouth to influence their close associates to buy products via Shopee's website. It is a powerful marketing tool as consumers believe and trust on people they care and value. In addition, they tend to believe advices given by people, whom they believe will not betray or harm them (See, Nor, \& Al-Agaga, 2012).

\section{Limitations and Directions for Future Research}

There are a few limitations that the researcher encountered while collecting the research data for completing the process of this study. Firstly, the sample size in this research is considered small which might not able to represent for the whole target population. Furthermore, this research only focuses in one selected e-commerce platform which is Shopee and the only target area is in Johor Bahru to examine the relationship between factors influencing online purchase intention. Thus, there might be limited information gained for the overall results. There are few recommendations for the future research that needs to be developed to ensure a better research tends to be studied in the future. Firstly, there is a significant need to increase the sample size used in the study as the total of 90 respondents are not able to represent for the whole target population and the higher the target respondents might show a more accurate result finding. Secondly, the future researcher can emphasize on more than one e-commerce platform in Malaysia other than Shopee and also apply this study into the other states in Malaysia in order to obtain more significant results through the comparison between few e-commerce platforms.

\section{Acknowledgements}

This work was supported/funded by the Ministry of Higher Education under Fundamental Research Grant Scheme (FRGS/1/2019/SS03/UTM/02/8).

\section{References}

Aghdaie, S. F., Piraman, A., \& Fathi, S. (2011). An analysis of factors affecting the consumer's attitude of trust and their impact on internet purchasing behaviour. International Journal of Business and Social Science, 2(23), 147-158.

Agyapong, H. A. (2018). Exploring the influential factors of online purchase intention in Finland. Finland: Business Economics and Tourism International Business. 
Aineah, B. N. (2016). Factors influencing online purchasing intention among college students in Nairobi city. Unpublished master's thesis, United States International UniversityAfrica, Nairobi.

Ajzen, I. (1991). The theory of planned behaviour. Organizational Behaviour and Human Decision Processes, 50(2), 179-211.

Alatawy, K. S. (2018). Factors influencing consumers' intention to use mobile applications for online shopping in the Kingdom of Saudi Arabia (KSA). International Journal of Business and Management, 14(1), 86-94.

Athapaththu, J. C. \& Kulathunga, D. (2018). Factors affecting online purchase intention: effects of technology and social commerce. International Business Research, 11(10), 111-128.

Athapaththu, J. C., \& Kulathunga, K. M. S. D. (2018). Factors affecting online purchase intention: A study of Sri Lankan online customers. International Journal of Scientific \& Technology Research, 7(9), 120-128.

Awang, Z. (2012). Validating the measurement model: CFA. Retrieved 14, March 2019 from file:///C:/Users/Asus/Downloads/7Chapter3AnalyzingtheMeasurementModel.pdf

Cha, J. (2011). Exploring the internet as a unique shopping channel to sell both real and virtual items: A comparison of factors affecting purchase intention and consumer characteristics. Journal of Electronic Commerce Research, 12(2), 115-132.

Cheng, B. L., \& Yee, S. W. (2014). Factors influencing consumers' online purchase intention: A study among university students in Malaysia. International Journal of Liberal Arts and Social Science, 2(8), 121-133.

Chin, C. (2016). Malaysians not buying into online shopping. Retrieved 20, March 2019 from https://www.thestar.com.my/news/nation/2016/10/23/malaysians-not-buying-intoonline-shopping/

Chiu, Y. B., Ling, C. P., \& Tang, L. L. (2005). “Gender differs: Assessing a model of online purchase intentions in e-tail service", International Journal of Service Industry Management, 16(5), 416-435.

Compeau, D. R., Higgins, C. A., and Huff, S. (1999). Social cognitive theory and individual reactions to computing technology: A longitudinal-study. Management Information Systems Quarterly, 23(2), 145-158.

Chen, Y., and Barnes, S. (2007), Initial trust and online buyer behaviour, Industrial $\begin{array}{llll}\text { Management \& Data Systems, 107(1), 21-36. } & \text {. }\end{array}$ https://doi.org/10.1108/02635570710719034

Dharmesti, M., Dharmesti, T. R. S., Kuhne, S., and Thaichon, P. (2019), Understanding online shopping behaviours and purchase intentions amongst millennials, Young Consumers, https://doi.org/10.1108/YC-12-2018-0922

Davis, F. D. (1989). Perceived usefulness, perceived ease of use, and user acceptance of information technology. Management Information Systems Quarterly, 13(3), 319-340.

Elfil, M., \& Negida, A. (2017). Sampling methods in clinical research; an educational review. Emerg (Tehran), 5(1), 52.

Fornell, C., \& Larcker, D. F. (1981). Evaluating structural equation models with unobservable variables and measurement error. Journal of Marketing Research, 18(1), 39-50.

Gefen, D., Karahanna, E., \& Straub, D. W. (2003). Trust and TAM in online shopping: An integrated model. MIS Quarterly, 27(1), 51-90.

Hair, J. F., Black, W. C., Babin, B. J., \& Anderson, R. (2010). Multivariate data analysis (7th ed.). Upper Saddle River: Pearson Education. 
Hair, J. F., Hult, G. T. M., Ringle, C. M., \& Sarstedt, M. (2017). A primer on partial least squares structural equation modeling (PLS-SEM). Los Angeles: SAGE.

Hana, B. S., Mike, M., \& Parvaneh, N. (2012). E-commerce is the next frontier in global expansion. New York: ATKearney.

Harn, A. C., Khatibi, A., Ismail, H. (2006). E-Commerce: A Study on Online Shopping in Malaysia. Journal of Social Science, 13(3), 231-242.

Hasan, H., Harun, A., \& Rashid, M. S. Z. (2015). Factors influencing online purchase intention in online brand. International Journal of Business Management \& Research (IJBMR), 5(5), 63-72.

Juniwati. (2014). Influence of perceived usefulness, ease of use, risk on attitude and intention to shop online. European Journal of Business and Management,6(27), 218-228.

Khatibi, A., Thyagarajan, V., \& Seetharaman, A. (2003). E-commerce in Malaysia: Perceived benefits and barriers. Vikalpa, 28(3), 77-82.

Koththagoda, K. C., \& Herath, H. M. R. P. (2018). Factors influencing online purchase intention: The mediation role of consumer attitude. Journal of Marketing and Consumer Research, 42, 66-74.

Koufaris, M., \& Sosa, W. H. (2004). The development of initial trust in an online company by new customers. Information \& Management, 41, 377-397.

Lee, G., \& Lin, H. (2005). Customer perceptions of e-service quality in online shopping. International Journal of Retail \& Distribution Management, 33(2), 161-176.

Letchumanan, M., \& Muniandy, B. (2013). Migrating to e-book: a study on perceived. Library Hi Tech News, 7, 10-15.

Lim, Y. J., Osman, A., Salahuddin, S. N., Romle, A. R., \& Abdullah, S. (2015). Factors influencing online shopping behavior: The mediating role of purchase intention. Procedia Economics and Finance, 35, 401-410.

Liu, C., Bao, Z., and Zheng, C. (2019), Exploring consumers' purchase intention in social commerce: An empirical study based on trust, argument quality, and social presence, Asia Pacific Journal of Marketing and Logistics, 31(2), 378-397. https://doi.org/10.1108/APJML-05-2018-0170

Malaysian Communications and Multimedia Commission. (2019). Internet users survey 2018. Retrieved 20, March 2019 from

https://www.mcmc.gov.my/skmmgovmy/media/General/pdf/Internet-Users-Survey-2018(Infographic).pdf

McKnight, D. H., \& Chervany, N. L. (2001). What trust means in e-commerce customer relationships: An interdisciplinary conceptual typology. International Journal of Electronic Commerce, 6(2), 35-59.

Messick, S. (1995). Standards of validity and the validity of standards in performance assessment. Educational Measurement: Issues and Practice, 14(4), 5-8.

Mohajan, H. K. (2017). Two criteria for good measurements in research: Validity and reliability. Annals of Spiru Haret University, 17(3), 58-82.

Nguyen, T. D., \& Barrett, N. J. (2006). The adoption of the internet by export firms in transitional markets. Asia Pacific Journal of Marketing and Logistics, 18(1), 29-42.

Nunnally, J. C. (1978). Psychometric theory (2nd ed.). New York: McGraw-Hill.

Pallant, J. (2011). A step by step guide to data analysis using the SPSS program: Survival manual (4th ed.). McGraw-Hill: Berkshire. 
Rehman, S. U. (2018). Impact of financial risk, privacy risk, convenience, and trust on online shopping with mediating role of consumer purchase intention in Pakistan. International Journal of Academic Multidisciplinary Research (IJAMR), 2(8), 27-34.

Reibstein, D. J. (2002). What attracts customers to online stores, and what keeps them coming back? Journal of the Academy of Marketing Science, 30(4), 465-473.

See, S. S., Nor, K. M., \& Al-Agaga, A. M. (2012). Factors affecting Malaysian young consumers' online purchase intention in social media websites. Procedia - Social and Behavioral Sciences, 40, 326-333.

Straub, D. W. (1989). Validating instruments in MIS research. MIS Quarterly, 13(2), 147-169.

Taherdoost, H. (2016). Validity and reliability of the research instrument: How to test the validation of a questionnaire/survey in a research. International Journal of Academic Research in Management (IJARM), 5(3), 28-36.

Tan Y. H., \& Thoen W. (2001). Toward a generic model of trust for electronic commerce. International Journal of Electronic Markets, 5(2), 61-74.

Tan, P. K., Goh, H. B., Stany, W. L. F., \& Yeow, J. A. (2017). Factors that influence the consumer purchase intention in social media websites. International Journal of Supply Chain Management, 6(4), 208-214.

Thatcher, R. (2010). Validity and reliability of quantitative electroencephalography. Journal of Neurotherapy, 14, 122-152.

TimeTrade. (2019). Study: $85 \%$ of consumers prefer to shop at physical stores vs. online. Retrieved 20, March 2019 from https://www.timetrade.com/about/newsevents/news-item/study-85-of-consumers-prefer-to-shop-at-physical-stores-vsonline/

Twycross, A., \& Shields, L. (2004). Validity and reliability- What's it all about? Part 2: Reliability in quantitative studies. Paediatric Nursing, 16(10), 36.

Thamizhvanan, A., and Xavier, M. J. (2013), Determinants of customers' online purchase intention: an empirical study in India, Journal of Indian Business Research, 5(1), 17-32. https://doi.org/10.1108/17554191311303367

Wright, S. (1921). Correlation and causation. Journal of Agricultural Research, 20, 557-585.

Zhao, Z., \& Cao, Q. (2012). An empirical study on continual usage intention of microblogging: The case of Sina. Nankai Business Review, 3(4), 413-429. 